Dawes, P. R. \& Soper, N. J. 1973: Pre-Quaternary history of North Greenland. In Pitcher, M. G. (edit.) Arctic Geology. Mem. Am. Ass. Petrol. Geol. 19, 117-134.

Dunbar, C. O. 1963: Trends of evolution in American fusulines. In Von Koenigswald, G. H. et al. (edit.) Evolutionary trends in Foraminifera, 26-44. Amsterdam: Elsevier Publ.

Peel, J. S., Dawes, P. R. \& Troelsen, J. C. 1974: Notes on some Lower Palaeozoic to Tertiary faunas from eastern North Greenland. Rapp. Grønlands geol. Unders. 65, 18-23.

Ross, C. A. 1967: Development of fusulinid (Foraminiferida) faunal realms. J. Paleontol. 41, 1341-1354.

Thompson, M. L. 1961: Pennsylvanian fusulinids from Ward Hunt Island.J. Paleontol. 35, 1130-1141.

Thorsteinsson, R. 1960: Permian fusulinids of Grinnell Peninsula. In Harker, P. \& Thorsteinsson, R. (edit.) Permian rocks and faunas of Grinnell Peninsula, Arctic Archipelago. Mem. geol. Surv. Can. 309, 21-38.

Thorsteinsson, R. \& Tozer, E. T. 1970: Geology of the Arctic Archipelago. In Douglas, R. J. W. (edit.) Geology and economic minerals of Canada. Econ. Geol. Rep. geol. Surv. Can. 1, 548-590.

Toomey, D. F. 1969: The biota of the Pennsylvanian (Virgilian) Leavenworth Limestone, midcontinent region. Pt. 2: Distribution of algae. J. Paleontol. 43, 1313-1330.

Toomey, D. F. 1972: The biota of the Pennsylvanian (Virgilian) Leavenworth Limestone, midcontinent region. Pt. 3: Distribution of calcareous Foraminifera. J. Paleontol. 46, 276-298.

Troelsen, J. [C.] 1950: Geology. In Winther, P. C. et al. A preliminary account of the Danish Pearyland Expedition, 1948-9. Arctic 3, 6-8.

Québec Department of Natural Resources, Energy Branch, Exploration Division, 1305 Chemin Ste-Foy, Québec G1S $4 N 5$,

Canada.

\title{
A reconnaissance of Quaternary deposits in northern Greenland
}

\author{
Anker Weidick
}

The main aim of the 1976 field work was an investigation of the extent of Quaternary deposits in the central part of Olrik Fjord, north of Thule Air Base, North-West Greenland. In addition, other localities were visited across northern Greenland to locate and collect samples for $\mathrm{C}^{14}$ dating in order to supplement the hitherto sparce evidence of Holocene deglaciation and uplift of this region, i.e. at Narssârssuk, south of Thule Air Base, central Hall Land, J. P. Koch Fjord, and the delta of Børglum Elv in Peary Land (fig. 8).

\section{Olrik Fjord}

Olrik Fjord is $80 \mathrm{~km}$ long. At its western junction with Hvalsund (Ikerssuaq) it is $8 \mathrm{~km}$ wide whereas its greatest part forms a $3-4 \mathrm{~km}$ wide channel penetrating plateau landscapes with surfaces at $800-1000 \mathrm{~m}$ above sea level. There are few earlier investigations of the Quater- 


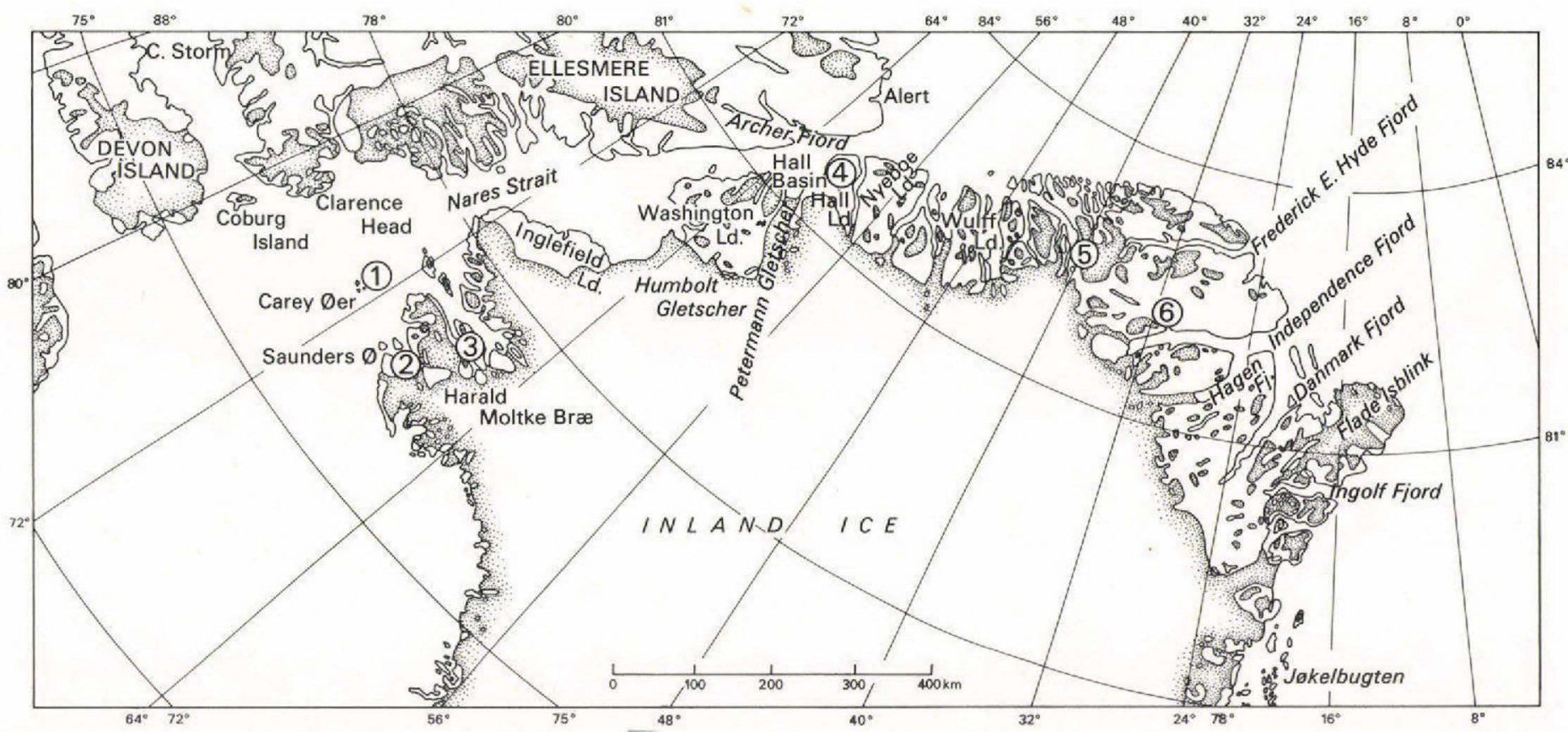

Fig. 8. Map of northern Greenland showing the location where Quaternary studies were undertaken. 1: Carey Øer; 2: Thule Air Base and Narssârssuk; 3: Olrik Fjord; 4: Hall Land; 5: J. P. Koch Fjord and front of Adams Gletscher; 6: Børglum Elv delta, Jørgen Brønlund Fjord, Peary Land. 
nary deposits of the fjord. Koch (1928) reports that the front of Marie Gletscher at the head of the fjord is resting partly on a $10 \mathrm{~m}$ delta surface, indicating a late Holocene readvance. The position of the front of this glacier seems to have been stationary at least since A.D. 1923 (Davies \& Krinsley, 1962).

Marine deposits were located in the central part of Olrik Fjord around eastern Kûgssuaq in 1974 by P. R. Dawes (personal communication) and a sample containing Chlamys islandica, Hiatella arctica and Mya truncata so collected furnished an age of $18990 \pm 280$ B.P. (I-8894, Weidick, 1976a, b). The age, in accordance with other dates around Nares Strait, indicates interstadial deposits. However, the occurrence of Chlamys islandica requires conditions comparable to or warmer than at the present time. Thus, the age might be due to a mixture of Holocene and older shells.

Field work in 1976 covered the central part of the northern shore of Olrik Fjord along a 25 km stretch between western Kûgssuaq to the east of eastern Kûgssuaq. The steep walls surrounding the inner fjord from Marie Gletscher to the investigated area exhibit mainly talus slopes, rock glaciers and, at lower levels, silty boulder rich moraines. From eastern Kûgssuaq and further west, the sides of the fjord becomes more gentle so that the shore is formed by widespread ground moraine, marine and fluviatile deposits partly with surfaces of wind-blown sand dunes, and stone plains at lower levels. Higher on the slopes a series of recessional moraines indicates a relatively continuous retreat of the Inland Ice through this part of the fjord after the last glaciation.

The marine limit through the investigated part of the fjord is $45 \pm 5 \mathrm{~m}$ above sea level and, although subjected to some solifluction, this limit at places is well defined. The marine limit might increase in height around western Kûgssuaq but this could not be clearly determined. A search for marine shell fragments in the silty moraine above the marine limit gave no result. Below this limit shell carrying deposits generally occur, either in moraine-like boulder rich silt in the cliffs facing the fjord and tributary brooks, or in the silty gravel surfaces of the terraces and in the foreset and topset beds of eastern Kûgssuaq delta. Deflation plains and local deposits of aeolian sand layers (at places intercalated with very thin turf lenses) occur in the western half of the investigated area.

No more shells of Chlamys islandica were found at Dawes' locality at eastern Kûgssuaq, but some were collected at another locality $15 \mathrm{~km}$ further west. These as well as other shell samples from the region will be subject to $\mathrm{C}^{14}$ dating.

\section{Narssârssuk}

At Narssârssuk $10 \mathrm{~km}$ south-west of Thule Air Base, an extensive delta surface with many terraces faces the coast. The terraces terminate seawards in 10-15 m high cliffs of silt covered with a veneer of gravel and boulders. The layers of stratified silt are extremely rich in shells. The terrace system and its fauna have previously been described by Davies et al. (1963) but no $\mathrm{C}^{14}$ dating of the fauna has been attempted. At Thule Air Base and a bay to the south, remnants of marine terraces can be seen, but the main parts are damaged by constructional activity. However, sufficient is left to indicate the marine limit of $38 \mathrm{~m}$ above sea level, as given by Davies et al. (1963). 


\section{Hall Land}

Reconnaissance of the eastern part of the depression which crosses Hall Land indicated more widespread marine deposits than described by Davies et al. (1959). Besides location and collection of samples for dating, the opportunity was taken to make a ground check on a topographic-geological map on the scale 1:50000 made by photo-interpretation (see Dawes, this report). Only few corrections were found to be necessary to the differentiation of Quaternary deposits established on this map. Altimeter determination of the marine limit $(100 \pm 10 \mathrm{~m}$ above sea level) fitted well with the photogrammetric determination of 106-110 $\mathrm{m}$ above sea level.

\section{Peary Land}

The reconnaissance of Peary Land was focused on an area east of the front of Adam Gletscher. The marine limit here is at $45 \pm 5 \mathrm{~m}$ above sea level (Weidick, 1976a) and is marked by a terrace of marine deposits covered by fluviatile gravel. At Børglum Elv at the entrance of Jørgen Brønlund Fjord, a short investigation of Uglegylpshøjen was made. The locality contains driftwood formerly dated to $>35000$ years B. P. (Fredskild, 1969). The occurrence of the driftwood seems to be connected to an ice wedge through the delta deposits of Børglum Elv, here consisting of sands and gravel with shells of presumably Holocene age.

\section{Acknowledgements}

The field work at Olrik Fjord was supported by a Greenlandair Charter Bell 204 helicopter stationed in Thule Air Base. Transport between Thule Air Base, Hall Land and Peary Land was supplied by the Royal Danish Air Force. A short visit to the Carey Øer was made possible by Dr. Weston Blake, Geological Survey of Canada, and the investigation of the Narssârssuk area by the use of a hovercraft of Mr. Erik Arnholt, Thule Air Base.

\section{References}

Davies, W. E. \& Krinsley, D. B. 1962: The recent regimen of the ice margin in North Greenland. Publs. Assoc. Int. Hydrol. Scient. 58, 119-130.

Davies, W. E., Krinsley, D. B. \& Nicol, A. H. 1963: Geology of the North Star Bugt area, Northwest Greenland. Meddr Grønland 162, 12, 68 pp.

Davies, W. E., Needleman, S. M. \& Klick, D. W. 1959: Report on Operation Groundhog (1958) North Greenland. Investigation of ice-free sites for aircraft landings, Polaris Promontory, North Greenland. 45 pp. Bedford: U.S. Air Force Cambridge Res. Lab.

Fredskild, B. 1969: A postglacial standard pollendiagram from Peary Land, North Greenland (1). Pollen Spores 11, 573-583.

Koch, L. 1928: Contributions to the glaciology of North Greenland. Meddr Grønland 65, 181-464. Weidick, A. 1976a: Glaciations of North Greenland - new evidence. Polarforschung 46, 26-33.

Weidick, A. 1976b: Quaternary observations in southern Peary Land, North Greenland. Rapp. Grønlands geol. Unders. 80, 15-17. 